Article

\title{
Fast Electrochemical Method for Organic Dye Decolorization Using Recycled Li-Ion Batteries
}

\author{
Eric M. Garcia *, Hosane A. Taroco and Rodrigo G. Teixeira
}

Department of Exact and Biological Sciences (DECEB), University of São João Del Rei-Sete Lagoas Campus, Sete Lagoas-MG 35701-970, Brazil; hataroco@hotmail.com (H.A.T.); rodrigoteixeira165@gmail.com (R.G.T.)

* Correspondence: ericmgmg@hotmail.com; Tel.: +55-(31)-3697-2003; Fax: +55-(31)-3697-2003

Received: 2 August 2018; Accepted: 9 August 2018; Published: 14 August 2018

\begin{abstract}
In this paper, the application of recycled Li-ion battery spent cathodes (LIB-SC) combined with a $\mathrm{NaHCO}_{3} / \mathrm{H}_{2} \mathrm{O}_{2}$ system is presented for the first time in the literature as an alternative for the degradation of potentially toxic organic molecules. The model pollutant choice was methylene blue molecule. The spent cathode composition corresponds to $\mathrm{LiCoO}_{2}$, which was proved by the XRD and EDX. Regarding the decolorization of methylene blue solution, the addition of $\mathrm{NaHCO}_{3}$, in comparison with only $\mathrm{H}_{2} \mathrm{O}_{2}$, reduces the complete decolorization time by $96 \%$. This reduction occurs because the radical $\mathrm{CO}_{3}$ is more stable than $\mathrm{OH}$. In this way, the application of the system proposed in this article is aimed at solving two major global problems: the disposal of cell phone batteries and the pollution of liquid effluents.
\end{abstract}

Keywords: rcycling; Li-ion; methylene blue; $\mathrm{LiCoO}_{2}$

\section{Introduction}

One of the first papers reporting the Li-ion battery (LIB) is dated 1962 [1]. Approximately 30 years passed before its introduction to the commercial market by Sony ${ }^{\circledR}$ [2]. The LIB rapidly replaced $\mathrm{NiCd}$ and NiMH batteries, generating a revolution in the production of electronic portable devices [3]. LIBs currently account for $37 \%$ of all batteries consumed in the world [4]. In order to give a sense of the dimensions of LIB presence in the market, in 2012, world sales of LIBs were estimated at $\$ 12$ billion, and this number was more than double that in 2015 (\$30 billion) [5].

Another application that has increased is hybrid devices between supercapacitors and Li-ion batteries. In these devices, the batteries' faradaic processes are combined with the capacitive processes of the supercapacitors, generating a new class of energy source. This new prospect for application is mainly related to the advent of electric vehicles [6-8].

Due to the current need for self-sustaining technologies, the recycling of Li-ion batteries (LIB) is a research topic that is growing stronger with each passing year. In LIB, the current density is generated by transport of $\mathrm{Li}^{+}$between the cathode (composed of intercalation oxides such as $\mathrm{LiCoO}_{2}$ or $\mathrm{LiCo}_{\mathrm{x}} \mathrm{Mn}_{\mathrm{y}} \mathrm{Ni}_{\mathrm{w}} \mathrm{O}_{2}$, with $\mathrm{x}+\mathrm{y}+\mathrm{w}=1$ ) and the lithiated graphitic carbon anode [9]. The electrolyte is typically $\mathrm{LiPF}_{6}$ dissolved in organic carbonates [5]. The cathode is the most abundant (around 25-30\% in mass) and valuable component in LIBs [3]. In the literature, there is a considerable number of articles about the recycling of Li-ion battery spent cathodes (LIB/SC) composed of $\mathrm{LiCoO}_{2}$. At laboratory scale, the first step of hydrometallurgical recycling is the detachment of the cathode from the $\mathrm{Al}$ current collector, followed by acid dissolution [9]. After dissolution, the metal cations are separated by application of a cationic resin [10]. Components such as $\mathrm{Co}$ and $\mathrm{Li}$ are recovered in forms such as $\mathrm{Co}(\mathrm{OH})_{2}$ and $\mathrm{Li}_{2} \mathrm{CO}_{3}$, and even the resynthesis of cathodic material has been proposed [9]. Although there are many studies on LIB/SC recycling, very few studies focus on the direct application of LIB/SC [11]. 
The recent literature describes the decolorization of methylene blue (MB) solution using LIB/SC (with $\mathrm{LiCoO}_{2}$ ) in the presence of $\mathrm{H}_{2} \mathrm{O}_{2}$ [11]. In this case, the $\mathrm{OH}$ - radical formation occurs through $\mathrm{LiCoO}_{2}$ delitiation promoted by the hydrogen peroxide reduction in (Equation (2)) [11]. The formation of the hydroxyl radical (OH·) was confirmed utilizing isopropanol (i-PrOH) as a scavenger [11].

$$
\begin{gathered}
\mathrm{H}_{2} \mathrm{O}_{2(\mathrm{aq})}+e^{-} \rightarrow \mathrm{OH}_{(\mathrm{aq})}+\mathrm{OH}_{(\mathrm{aq})}^{-} \\
\mathrm{LiCoO}_{2(\mathrm{~s})}+\rightarrow \mathrm{Li}_{(1-x)} \mathrm{CoO}_{2(\mathrm{~s})}+x \mathrm{Li}_{(\mathrm{aq})}^{+}+x e^{-}
\end{gathered}
$$

The literature shows that $\mathrm{NaHCO}_{3}$ can increase the rate of methylene blue decolorization promoted by $\mathrm{OH}$. radicals. This is expected when the bicarbonate anion is radical scavenger (Equation (3)) [12]. The radical $\mathrm{CO}_{3}$ is much more stable than $\mathrm{OH} \cdot$, which can be explained by the difference in its recombination constant. For the radical $\mathrm{OH}$, the recombination constant is around $10^{9} \mathrm{M}^{-1} \mathrm{~s}^{-1}$ against $4.25 \times 10^{6} \mathrm{M}^{-1} \mathrm{~s}^{-1}$ for the $\mathrm{CO}_{3}[12]$.

$$
\mathrm{OH}_{(\mathrm{aq})}+\mathrm{HCO}_{3(\mathrm{aq})}^{-} \rightarrow \mathrm{H}_{2} \mathrm{O}+\mathrm{CO}_{3(\mathrm{aq})} \quad k=1.0 \times 10^{7} \mathrm{M}^{-1} \mathrm{~s}^{-1}
$$

Thus, the objective of this paper is to study the methylene blue (model pollutant) decolorization using the Li-ion batteries spent cathode (LIB/SC) combined with $\mathrm{NaHCO}_{3} / \mathrm{H}_{2} \mathrm{O}_{2}$ system. The composition of LIB/SC was obtained using the XDR and EDX techniques. An electrochemical study was also performed using linear voltammetry to evaluate $\mathrm{OH}$. formation.

\section{Material and Methods}

\subsection{Obtaining and Characterization of Li-Ion Battery Spent Cathodes (LIB/SC)}

The Li-ion battery was manually dismantled and the spent cathode in tape form was separated. The cathode tape was heated at $200{ }^{\circ} \mathrm{C}$ for $5 \mathrm{~h}$ to remove organic solvents. A schematic showing the main parts of the Li-ion battery is shown in Figure 1. The spent Li-ion battery cathode (LIB-SC) tape was washed in distilled water to eliminate possible lithium salts (such as $\mathrm{LiPF}_{6}$ ) present in the electrolyte [11]. The crystalline structure of the spent Li-ion battery cathode tape was characterized by X-ray diffraction on a 200 B Rotaflex-Rigaku with $\mathrm{Cu} \mathrm{K}_{\alpha}$ irradiation, a Co filter, and a scanning speed of $0.02 \mathrm{~min}^{-1}$. The morphology of the spent Li-ion battery cathode tape was observed by Field-Emission Scanning Electron Microscopy on a JEOL JXA model 8900 RL equipped with an energy dispersive X-ray (EDX) detector.

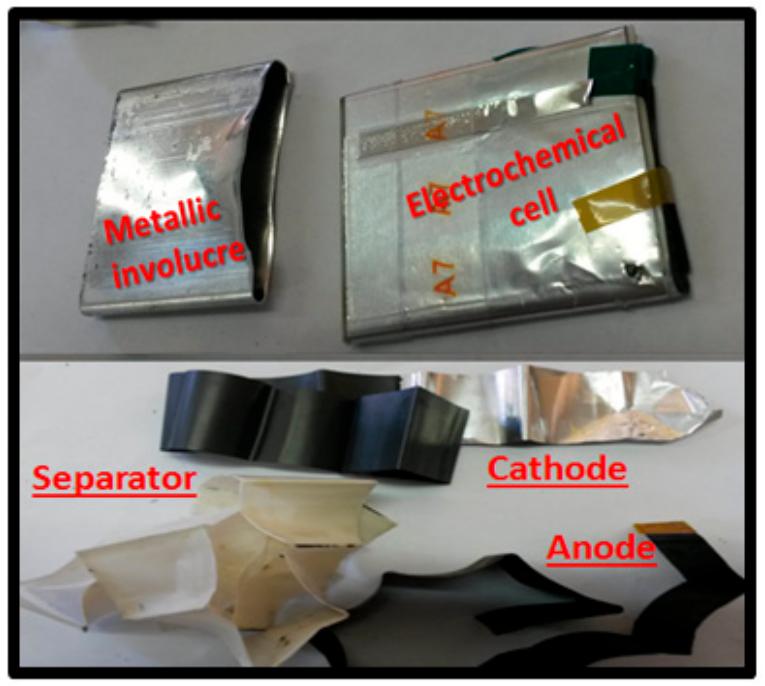

Figure 1. Dismantling scheme and obtaining of Li-ion battery spent cathodes (LIB/SC). 


\subsection{Methylene Blue Decolorization Analysis}

To study the MB decolorization kinetic, a $100 \mathrm{~mL}$ jacketed glass reactor containing $50 \mathrm{~mL}$ of MB solution was stirred magnetically $(10 \mathrm{rpm})$ in a temperature-controlled bath $\left(25^{\circ} \mathrm{C}\right)$. Before the addition of $\mathrm{H}_{2} \mathrm{O}_{2}$ and $\mathrm{NaHCO}_{3}$, the $\mathrm{MB}$ solution was put in contact with LIB-SC for $2 \mathrm{~h}$ to establish the adsorption equilibrium. The decolorization process was monitored by analyzing aliquots at $659 \mathrm{~nm}$ using a UV-Spectrophotometer FEMTO Cirrus 80 PR. All measurements were made in the absence of visible light to avoid the possible electron excitation of the cobalt lithium oxide conduction band to the valence band generating the electron (BC) and hole (BV) pair [11].

\subsection{Linear Voltammetry Measurements}

Linear voltammetry was performed using an AUTOLAB PGSTAT 30 power supply. The working electrode was made of Li-ion battery spent cathodes (LIB/SC). The samples were prepared as rectangular pieces $\left(1 \mathrm{~cm}^{-2}\right)$. The auxiliary electrode, with an area of $3.75 \mathrm{~cm}^{2}$, was made of platinum. A saturated $\mathrm{Ag} / \mathrm{AgCl}$ reference electrode was used. All the electrochemical measurements were performed at $25^{\circ} \mathrm{C}$. After the experiment, the resultant solution was analyzed with AAS, aiming to determine the possible lixiviation of $\mathrm{Co}$ and $\mathrm{Li}$.

\section{Results and Discussion}

\subsection{Characterization of Li-Ion Battery Spent Cathodes (LIB-SC)}

The characterization of Li-ion battery spent cathodes (LIB-SC) is very important, since composition varies with the make, and even with the model [11]. Figure 2 shows the X-ray diffraction of Li-ion battery spent cathodes (LIB-SC). According to comparison with the JCPDS card number 50-653, the main phase identified was in the $\mathrm{LiCoO}_{2}$. The presence of graphite is justified because its addition increases cathode conductivity. Through SEM (Figure 3a) it is possible to observe a very porous material, which may contribute to the rapid reaching of adsorption equilibrium. The porosity was calculated using the image ${ }^{\circledR}$ software, and the value was found to be $42 \%$, with an average grain size of $32 \mu \mathrm{m}^{2}$. The presence of fluorine is due to the binder polyvinylidene-fluoride (PVDF) (Figure 3b) [11].

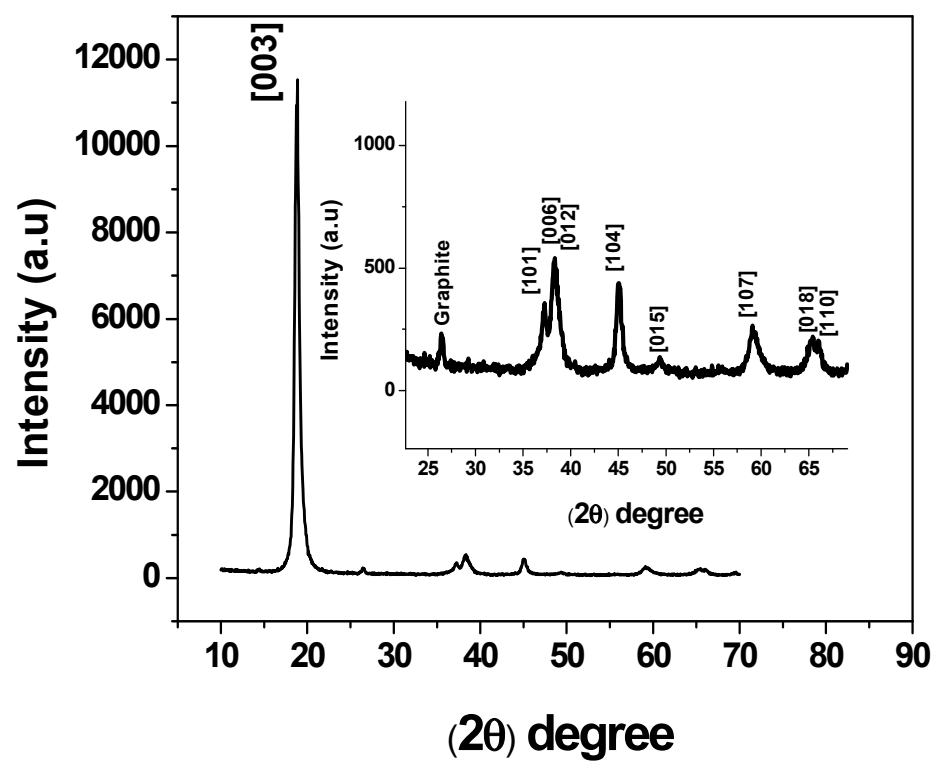

Figure 2. X-ray diffraction of Li-ion battery spent cathodes (LIB/SC) after heating at $200{ }^{\circ} \mathrm{C}$ for $5 \mathrm{~h}$. 


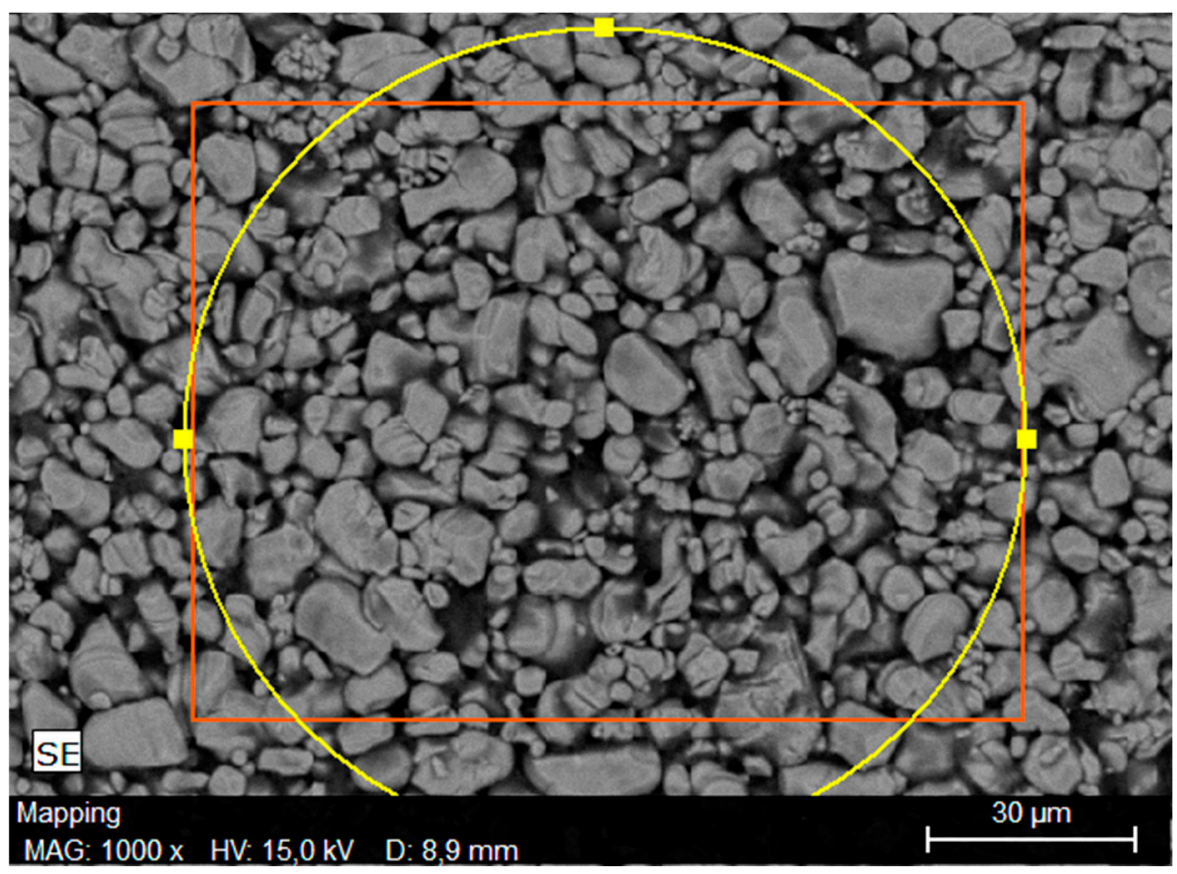

(a)

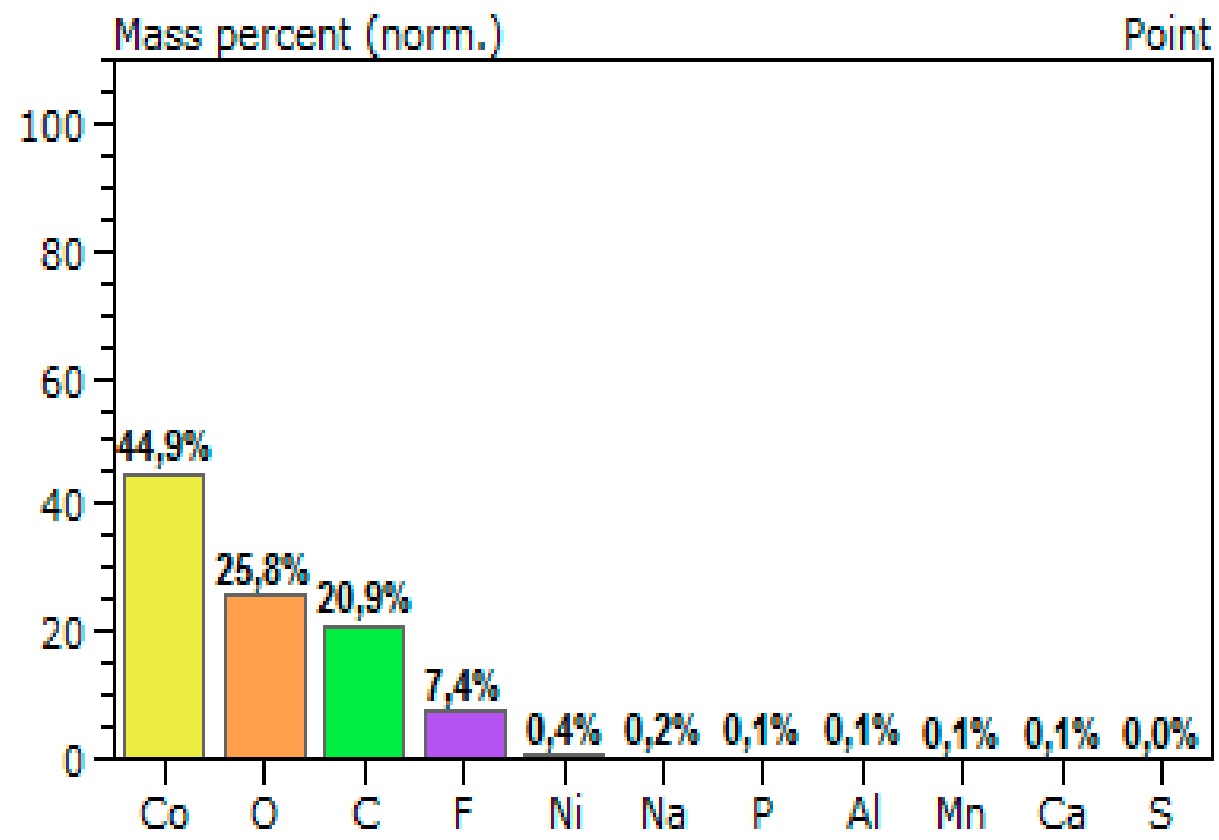

(b)

Figure 3. (a) Scan electronic microscopy (SEM) and (b) the average chemical composition obtained by energy dispersive X-ray (EDX) analyses of LIB/SC after heating at $200{ }^{\circ} \mathrm{C}$ for $5 \mathrm{~h}$.

\subsection{Decolorization of $\mathrm{MB}$ Solution Using $\mathrm{LIB}-\mathrm{SC}+\mathrm{H}_{2} \mathrm{O}_{2} / \mathrm{NaHCO}_{3}$ System}

Figure 4 a shows the variation of $[\mathrm{MB}] /\left[\mathrm{MB}_{0}\right]$ vs. time (where $[\mathrm{MB}]_{0}$ is the initial $\mathrm{MB}$ concentration) using $\mathrm{H}_{2} \mathrm{O}_{2}$ and LIB-SC. From Figure 4, the great influence of LIB-SC on the MB decolorization reaction can be clearly observed, as already described in the literature [11]. In this reaction, the $\mathrm{H}_{2} \mathrm{O}_{2}$ electrochemical reduction promoted by $\mathrm{LiCoO}_{2}$ delitiation is related to the first step [11]. 
The subsequent step is the attachment of $\mathrm{OH}$. onto the $\mathrm{MB}$ molecule. In the literature, this step is commonly described as the reaction-determinant step (rds) and is dependent on $\mathrm{OH}$ and $\mathrm{MB}$ concentrations [12]. In consideration of the fact that the electrochemical step maintains a practically fixed concentration of $\mathrm{OH}$, the most appropriate kinetic model is the pseudo first-order reaction, as represented by Equation (4) (where $k_{a p p}$ is the apparent velocity constant) [12]. Figure $4 \mathrm{~b}$ shows the linearity of $\ln [\mathrm{MB}] /[\mathrm{MB}]_{0}$ versus time as predicted for a first-order reaction (Equation (5)).

$$
\begin{gathered}
\frac{d[\mathrm{MB}]}{d t}=-k\left[\mathrm{OH} \cdot[\mathrm{MB}] \approx-k_{a p p}[\mathrm{MB}]\right. \\
\frac{[\mathrm{MB}]}{[\mathrm{MB}]_{0}}=\exp \left(-k_{a p p} t\right)
\end{gathered}
$$

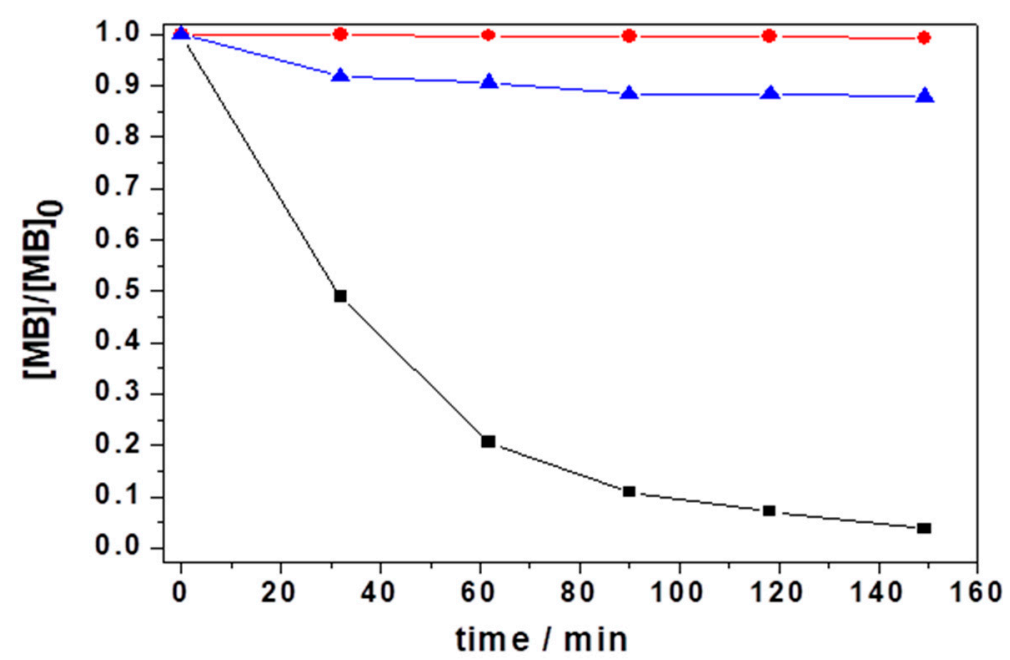

(a)

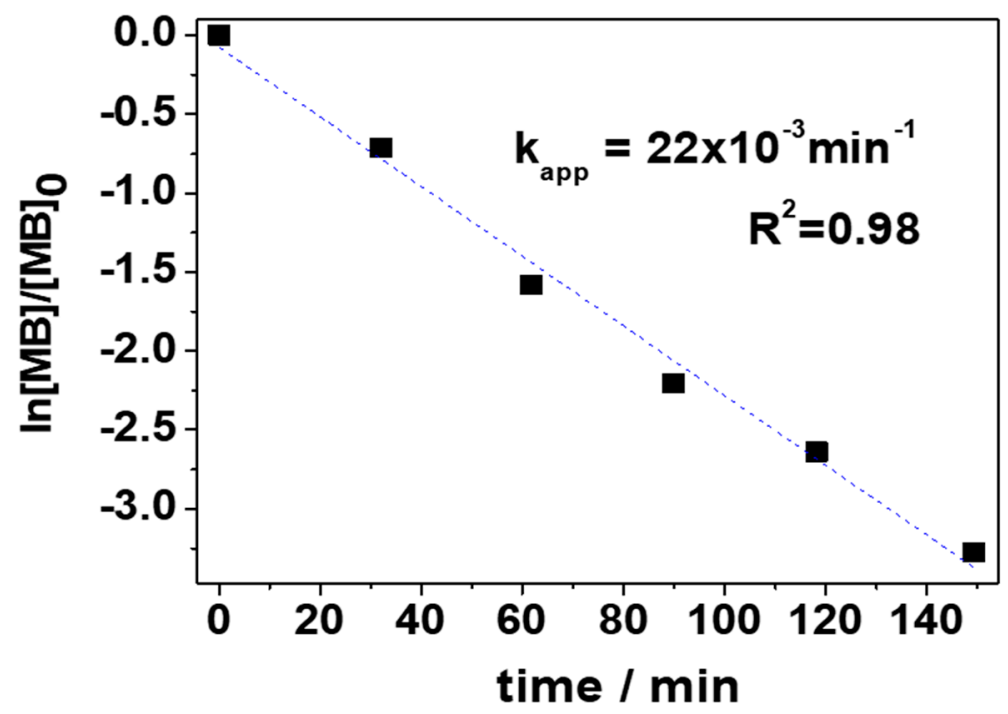

(b)

Figure 4. (a) Decolorization of $\mathrm{MB}$ solution under different conditions. Only $[\mathrm{MB}]=6 \mathrm{ppm}$ (red). $[\mathrm{MB}]=6 \mathrm{ppm}+\left[\mathrm{H}_{2} \mathrm{O}_{2}\right]=0.03 \mathrm{M}$ (blue). With LIB-SC $\left(\right.$ area $\left.=16 \mathrm{~cm}^{-2} \sim 400 \mathrm{mg}\right)+[\mathrm{MB}]=6 \mathrm{ppm}+$ $\left[\mathrm{H}_{2} \mathrm{O}_{2}\right]=0.03 \mathrm{M}$ (black). (b) $\ln [\mathrm{MB}] /[\mathrm{MB}]_{0}$ versus time. 
Figure 5 shows the decolorization of MB solution using $\mathrm{H}_{2} \mathrm{O}_{2}$ and $\mathrm{LIB}$ spent cathode and $\mathrm{HCO}_{3}{ }^{-}$. From Figure 5, one can see that the addition of $\mathrm{HCO}_{3}{ }^{-}$significantly increased the kinetics of $\mathrm{MB}$ decolorization when the bicarbonate anion was the radical scavenger (Equation (3)) [12]. The addition of $\mathrm{NaHCO}_{3}$ reduces the time for complete decolorization from $150 \mathrm{~min}$ to $6 \mathrm{~min}$. Thus, to better understand the role of each component in the $\mathrm{MB}$ decolorization reaction, of the following parameters were varied: $[\mathrm{MB}]_{0},\left[\mathrm{HCO}_{3}{ }^{-}\right],\left[\mathrm{H}_{2} \mathrm{O}_{2}\right]$ and LIB-SC area.

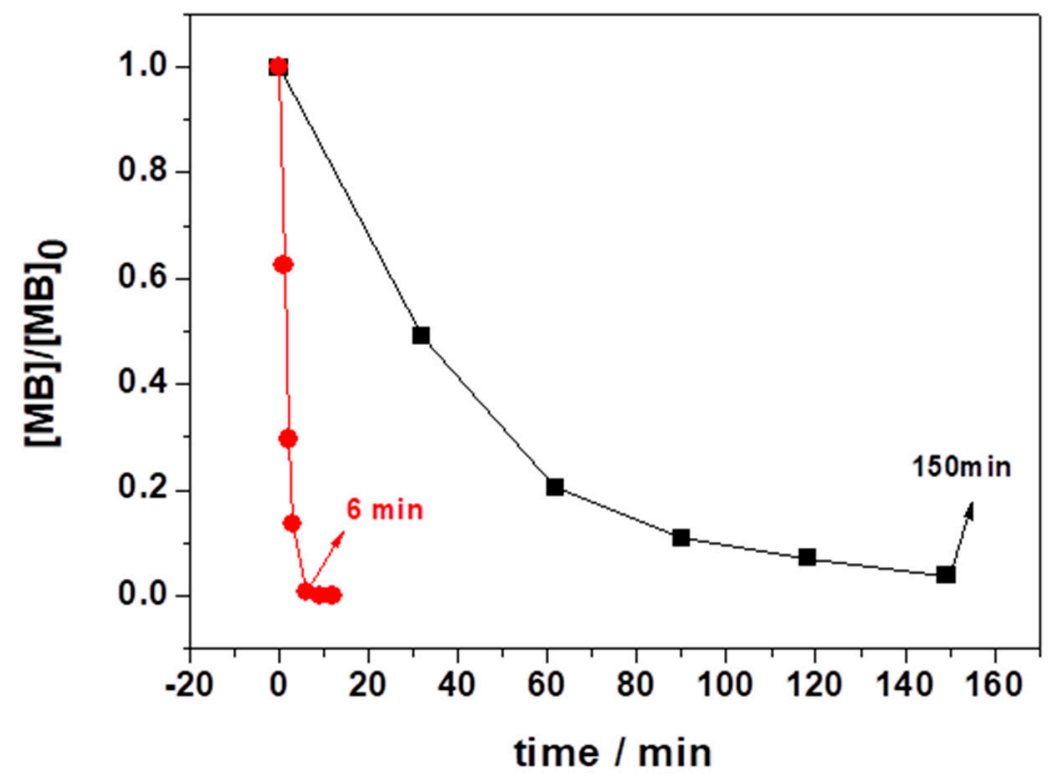

Figure 5. Decolorization of MB solution in different conditions: $[\mathrm{MB}]=6 \mathrm{ppm}+\left[\mathrm{H}_{2} \mathrm{O}_{2}\right]=0.03 \mathrm{M}+\mathrm{LIB}$ spent cathode tape $\left(\right.$ area $=16 \mathrm{~cm}^{-2}$ ) (Black). $[\mathrm{MB}]=6 \mathrm{ppm}+\mathrm{H}_{2} \mathrm{O}_{2}=0.03 \mathrm{M}+\mathrm{LIB}-\mathrm{SC}\left(\operatorname{area}=16 \mathrm{~cm}^{-2}\right)$ $+\left[\mathrm{NaHCO}_{3}\right]=0.01 \mathrm{M}$ (red).

\subsubsection{Variation of $[\mathrm{MB}]_{0}$ and LIB-SC Area in Decolorization of MB Using LIB-SC $+\mathrm{H}_{2} \mathrm{O}_{2} / \mathrm{NaHCO}_{3}$ System}

Figure 6 shows that $[\mathrm{MB}]_{0}$ variation promotes a modification in the $[\mathrm{MB}] /[\mathrm{MB}]_{0}$ vs. time profile. However, this behavior is not expected for a first-order reaction (or pseudo first-order reaction), since the $[\mathrm{MB}] /[\mathrm{MB}]_{0}$ vs. time curve must be an exponential curve that is dependent only on kapp, such as that shown in Equation (5). The influence of dye initial concentration is reported in the literature for heterogeneous Fenton-like catalyst [13]. Considering that adsorption equilibrium is reached quickly, initially, the catalyst surface is saturated with $\mathrm{MB}$ molecules, causing the reaction to initially follow zero-order kinetics (Equation (6)) [13]. Thus, under zero-order kinetics, the [MB]/[MB $]_{0}$ vs. time curve (represented in the Equation (7)) has a $[\mathrm{MB}]_{0}$-dependent angular coefficient (kapp/zero). The linear fit in the early moments of the reaction reveal that the kapp/zero changes from 0.32 to $0.10 \mathrm{~min}^{-1}$ when the initial concentration of methylene blue changes from 12 to $6 \mathrm{ppm}$, respectively.

$$
\begin{gathered}
\frac{d[\mathrm{MB}]}{d t} \approx-k_{\text {app }}[\mathrm{MB}] \approx-k_{\text {app } / \text { zero }} \\
\frac{[\mathrm{MB}]}{[\mathrm{MB}]_{0}}=1-\frac{k_{\text {app }} t}{[\mathrm{MB}]_{0}}
\end{gathered}
$$

It is important to note that $\mathrm{Fe}_{3} \mathrm{O}_{4}$ is a very popular catalyst for dye organic pollutants and other toxic substances due to its high efficiency, as well as its magnetic separation from the reaction medium [13]. In the literature, $\mathrm{Fe}_{3} \mathrm{O}_{4}$ nanoparticles are used for $10 \mathrm{ppm} \mathrm{MB}$ degradation using only $\mathrm{H}_{2} \mathrm{O}_{2}$ (without the use of $\mathrm{NaHCO}_{3}$ ) [13]. The time required for total decolorization was $120 \mathrm{~min}$. In our work, a solution of $12 \mathrm{ppm}$ was completely discolored in $36 \mathrm{~min}$ ( $0.5 \%$ of color-highlighted in Figure 6). 


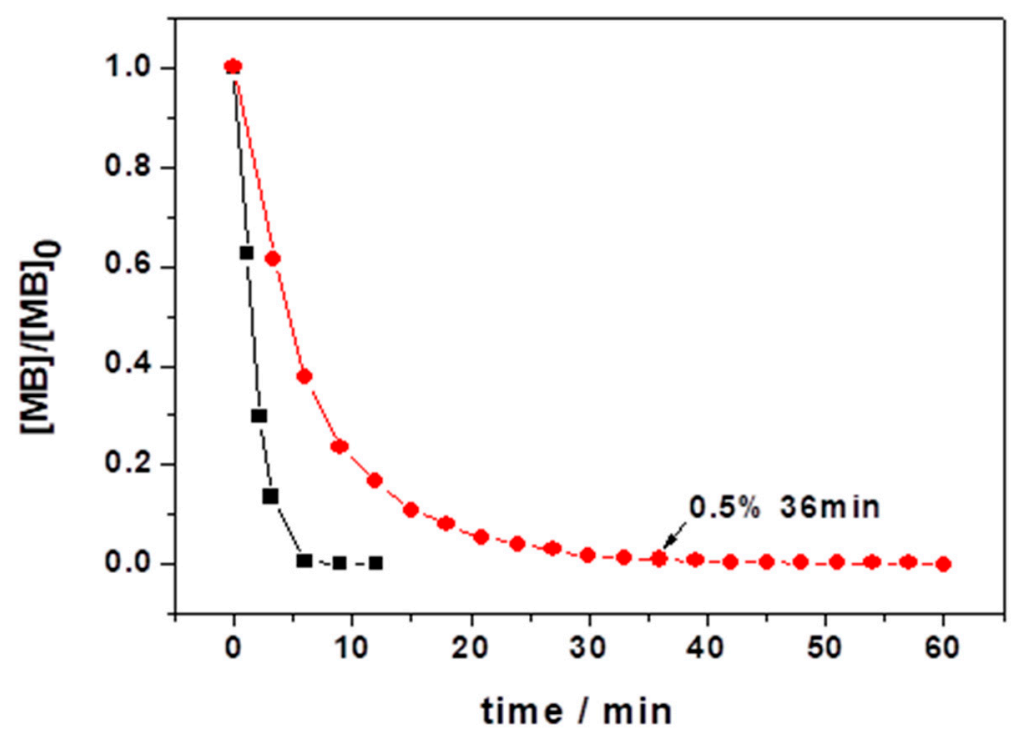

Figure 6. Decolorization of $\mathrm{MB}$ solution with two different $[\mathrm{MB}]_{0}: 6 \mathrm{ppm}$ (black) and $12 \mathrm{ppm}$ (red). In both cases, $\left[\mathrm{H}_{2} \mathrm{O}_{2}\right]=0.03 \mathrm{M}+\operatorname{LIB}-\mathrm{SC}\left(\right.$ area $\left.=16 \mathrm{~cm}^{-2}\right)+\left[\mathrm{NaHCO}_{3}\right]=0.01 \mathrm{M}$ was used.

Figure 7 shows the variation of the LIB-SC area in the methylene blue decolorization process. Since hydroxyl radicals are formed by $\mathrm{H}_{2} \mathrm{O}_{2}$ and LIB-SC electrochemical reaction, it is natural that the LIB-SC area is directly proportional to the hydroxyl initial concentration. The linear fit in the early moments of the reaction reveal that the kapp/zero decreases by a factor of 8 when the area undergoes a reduction of $16 \mathrm{~cm}^{2}$ to $2 \mathrm{~cm}^{2}$.

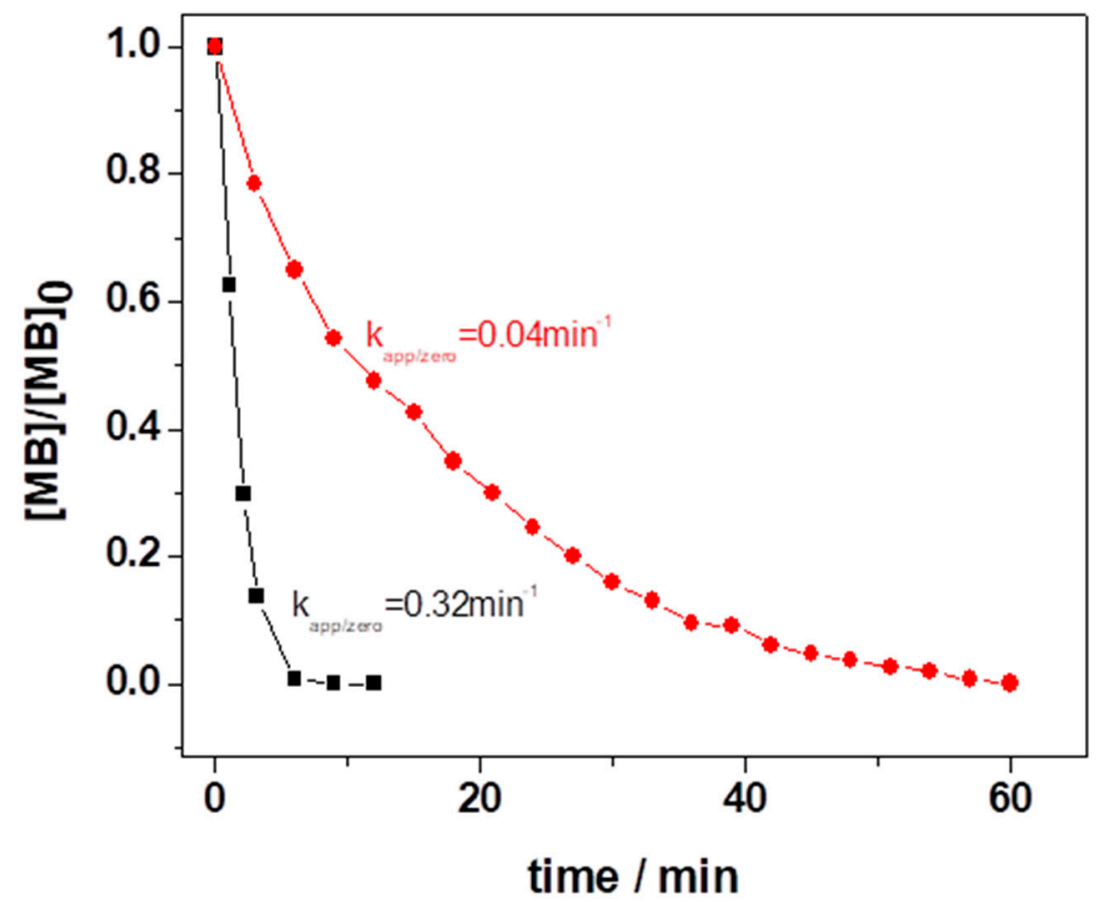

Figure 7. Decolorization of MB solution with two different LIB-SC areas: $16 \mathrm{~cm}^{-2}$ (black) and $1 \mathrm{~cm}^{-2}$ (red). In both cases, $[\mathrm{MB}]=6 \mathrm{ppm}+\left[\mathrm{H}_{2} \mathrm{O}_{2}\right]=0.03 \mathrm{M}+$ LIB spent cathode tape $\left(\right.$ area $=16 \mathrm{~cm}^{-2}+$ $\left[\mathrm{NaHCO}_{3}\right] 0.01 \mathrm{M}$ was used. 
3.2.2. Variation of $\left[\mathrm{H}_{2} \mathrm{O}_{2}\right]_{0}$ and $\left[\mathrm{NaHCO}_{3}\right]_{0}$ in Decolorization of MB Using LIB-SC $+\mathrm{H}_{2} \mathrm{O}_{2} / \mathrm{NaHCO}_{3}$ System

Figure $8 \mathrm{a}, \mathrm{b}$ shows the variation of $\mathrm{NaHCO}_{3}$ and $\mathrm{H}_{2} \mathrm{O}_{2}$ concentration in $\mathrm{MB}$ decolorization, respectively. It would be expected that with an increase in $\mathrm{NaHCO}_{3}$ concentration, there would be an increase in $\mathrm{CO}_{3}$ concentration, which would lead to an increase in $\mathrm{MB}$ decolorization rate. However, what is observed is that with $\mathrm{NaHCO}_{3}$ increase from 0.01 to $0.03 \mathrm{~mol} \cdot \mathrm{L}^{-1}$, there is a subtle decrease in the $\mathrm{MB}$ decolorization rate. This effect is probably linked to the recombination of $\mathrm{CO}_{3}$ Radicals, as shown in Equation (3).

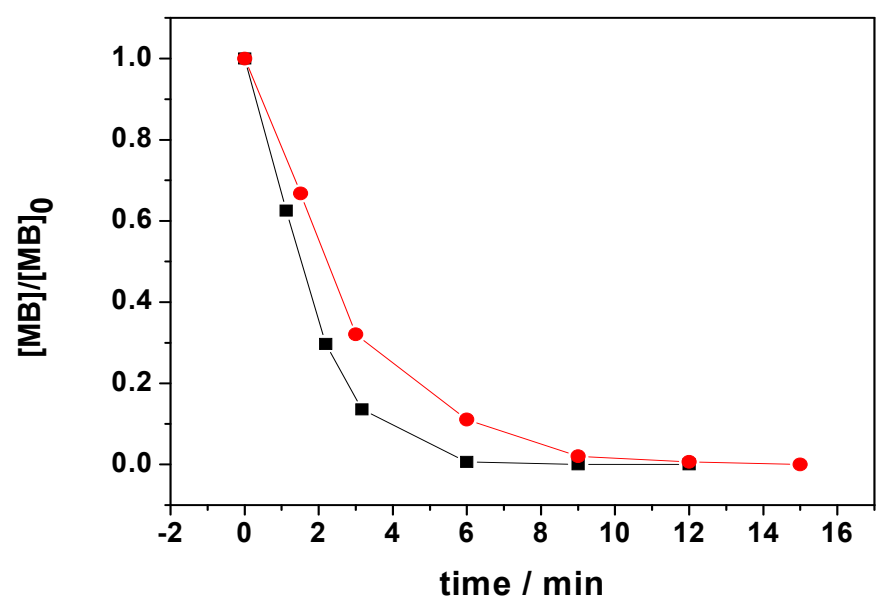

(a)

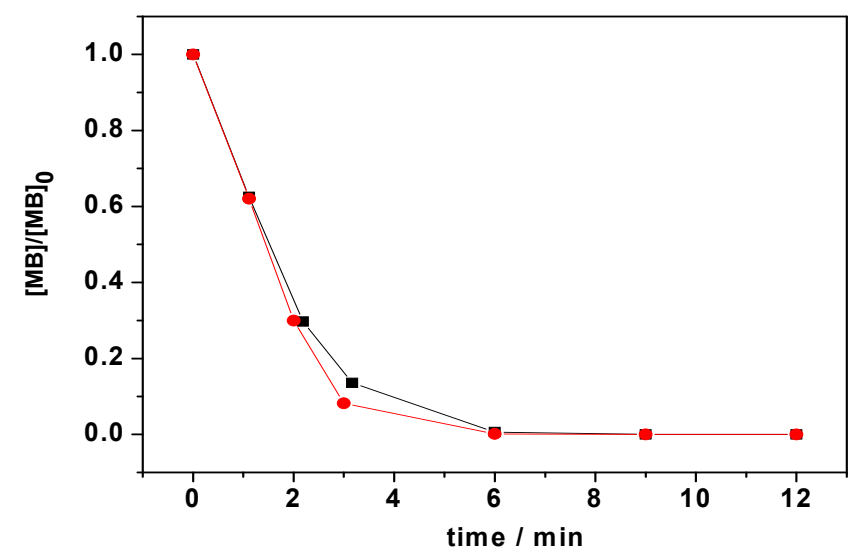

(b)

Figure 8. (a) Decolorization of $\mathrm{MB}$ solution with two different $\left[\mathrm{NaHCO}_{3}\right]$ : (black) 0.01 and 0.03 (red). In both cases, $\left[\mathrm{H}_{2} \mathrm{O}_{2}\right]=0.03 \mathrm{M}+\mathrm{LIB}-\mathrm{SC}\left(\right.$ area $\left.=16 \mathrm{~cm}^{-2}\right)+[\mathrm{MB}]=6 \mathrm{ppm}$ was used. $(\mathbf{b})$ Decolorization of MB solution with two different $\left[\mathrm{H}_{2} \mathrm{O}_{2}\right]$ : (black) 0.03 and 0.01 (red) In both cases, $\left[\mathrm{NaHCO}_{3}\right]=0.01 \mathrm{M}$ + LIB-SC $\left(\right.$ area $\left.=16 \mathrm{~cm}^{-2}\right)+[\mathrm{MB}]=6 \mathrm{ppm}$ was used.

The increase in peroxide concentration has a negligible influence on the reaction rate of $\mathrm{MB}$ decolorization (Figure 8b). On the other hand, the peroxide concentration should influence the reaction rate, since it is a reagent of the electrochemical step, as shown in Equation (1). However, peroxide is also a scavenger of $\mathrm{OH}$. radicals, producing hydroperoxyl radicals $\left(\mathrm{HO}_{2}\right)$ (Equation (8)).

$$
\mathrm{OH}_{(\mathrm{aq})}+\mathrm{H}_{2} \mathrm{O}_{2(\mathrm{aq})} \rightarrow \mathrm{H}_{2} \mathrm{O}+\mathrm{HO}_{2(\mathrm{aq})} \quad k=3.3 \times 10^{7} \mathrm{M}^{-1} \mathrm{~s}^{-1}
$$

As described in the literature, the $\mathrm{HO}_{2}$ generated in Equation [10] contributes very little to the process of organic molecule degradation [14]. 


\subsection{Linear Polarization Analyses and Co and Li Lixiviation}

In order to better investigate the electrochemical step of $\mathrm{MB}$ decolorization, Figure 9 shows the linear voltammetry of LIB-SC (area $=1 \mathrm{~cm}^{-2}$ ) in a solution with $\mathrm{MB}$ and the $\mathrm{H}_{2} \mathrm{O}_{2} / \mathrm{NaHCO}_{3}$ system. Table 1 shows some parameters obtained from linear voltammetry (Figure 9). The anodic branch refers to $\mathrm{LiCoO}_{2}$ delitiation (Equation (2)) and the cathodic branch corresponds to the reduction of $\mathrm{H}_{2} \mathrm{O}_{2}$ (Equation (1)). Considering the one electron charge transfer process as the limiting step, the Tafel coefficient must be near $118 \mathrm{mV} / \mathrm{dec}$. In this work, the deviations of this value can be attributed to an asymmetry in the charge transfer barrier, which could be caused by adsorption of MB [11]. The equilibrium potential (E) found is within the range expected for $\mathrm{LiCoO}_{2}$ in aqueous medium [15]. Considering one electron transfer $(n=1)$, an exchange current $(i)$ of $19 \times 10^{-2} \mathrm{Am}^{-2}$, a reaction system volume $(V)$ of $5 \times 10^{-2} \mathrm{~L}$, and an $F$ (Faraday constant) equal to $96,500 \mathrm{C} \cdot \mathrm{mol}^{-1}$, we can use Faraday's law (Equation (9)) to obtain the production rate of $\mathrm{Li}^{+}$ions in solution.

$$
\frac{d\left[\mathrm{Li}^{+}\right]}{d t}=\frac{i}{V n F}
$$

The value found was $4 \times 10^{-4} \mathrm{~mol} \cdot \mathrm{m}^{-3} \mathrm{~s}^{-1}$ (in the SI), or $4 \times 10^{-8} \mathrm{Ms}^{-1}$. Thus, after $5 \mathrm{~min}$, we should have a $\mathrm{Li}\left(7 \mathrm{~g} \cdot \mathrm{mol}^{-1}\right)$ concentration of around $0.084 \mathrm{ppm}$. Figure 10 shows the determination of lithium and cobalt after 5 and $60 \mathrm{~min}$ of reaction. The time of $5 \mathrm{~min}$ was chosen because this is the time interval necessary to degrade $6 \mathrm{ppm}$ of methylene blue. It can be observed that for the complete decolorization of the solution (approximately $5 \mathrm{~min}$ ), the cobalt leaching is below $0.015 \mathrm{ppm}$, and the corresponding value for lithium is $0.055 \mathrm{ppm}$. Despite the high efficiency, a disadvantage of the method is the leaching of $\mathrm{Li}$ and $\mathrm{Co}$ into the reaction medium.

Table 1. Some parameters obtained from linear voltammetry of LIB-SC ( area $=1 \mathrm{~cm}^{-2}$ ) in a solution with $\mathrm{MB}$ and $\mathrm{H}_{2} \mathrm{O}_{2} / \mathrm{NaHCO}_{3}$ system.

\begin{tabular}{cc}
\hline Parameter & Value \\
\hline $\mathrm{E}$ & $202.4 \mathrm{mV}$ \\
$\mathrm{i}$ & $56.46 \mu \mathrm{Acm}$ \\
$\mathrm{b}_{\mathrm{a}} \mathrm{Vdec}^{-1}$ & 0.152 \\
$\mathrm{~b}_{\mathrm{c}} \mathrm{Vdec}^{-1}$ & 0.096 \\
\hline
\end{tabular}

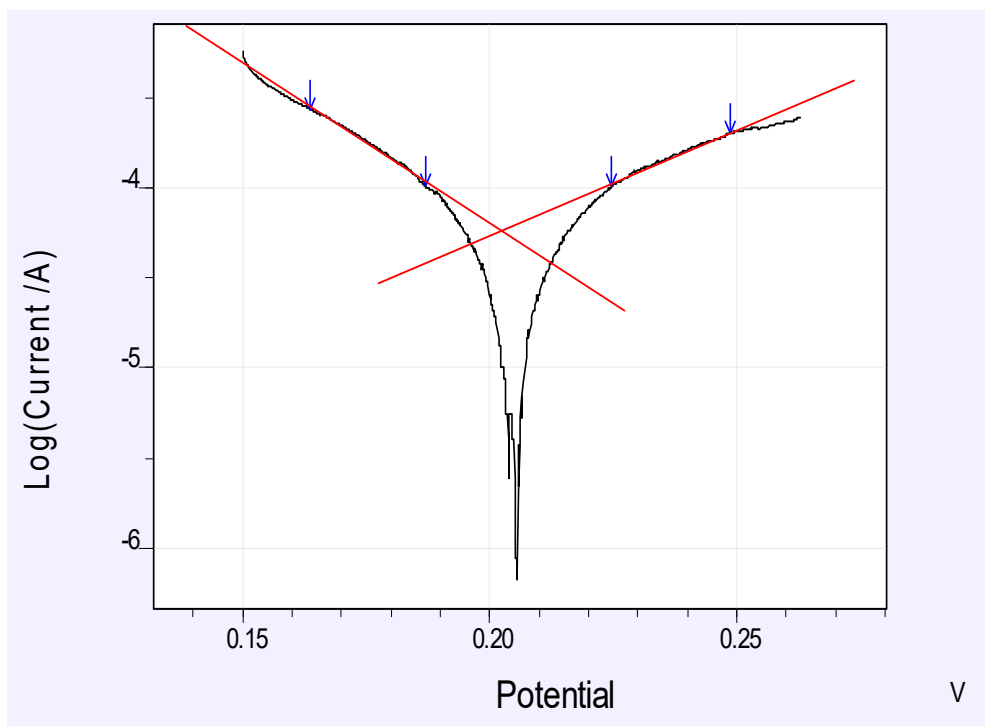

Figure 9. Linear voltammetry of LIB-SC $\left(\right.$ area $=1 \mathrm{~cm}^{-2}$ ) in a solution with $\mathrm{MB}$ and $\mathrm{H}_{2} \mathrm{O}_{2} / \mathrm{NaHCO}_{3}$ system $\left(\right.$ scan rate $\left.=1 \mathrm{mV} \cdot \mathrm{s}^{-1}\right)$. 


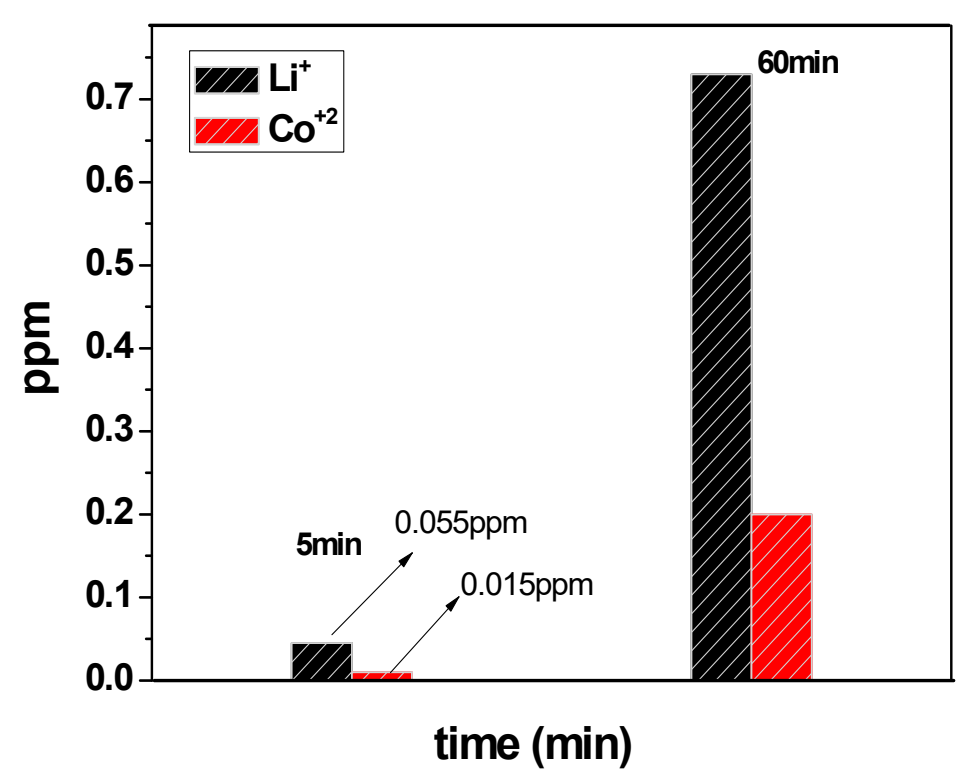

Figure 10. Lithium and cobalt detection using AAS after the discoloration of MB solution using: [MB] $=6 \mathrm{ppm}+\left[\mathrm{H}_{2} \mathrm{O}_{2}\right]=0.03 \mathrm{M}+\mathrm{LIB}$ spent cathode tape $\left(\right.$ area $\left.=16 \mathrm{~cm}^{-2}\right)+\left[\mathrm{NaHCO}_{3}\right]=0.01 \mathrm{M}$.

To evaluate the cyclability of the spent cathode, Figure 11 shows the successive cycles in the discoloration of $\mathrm{MB}$ solution using the $\mathrm{H}_{2} \mathrm{O}_{2} / \mathrm{NaHCO}_{3}$ system. It is clear that the material used in this work is not catalytic, as it wears out throughout the process. This occurs because the $\mathrm{OH}$. radical formation occurs through $\mathrm{LiCoO}_{2}$ delitiation promoted by hydrogen peroxide reduction, and the subsequent formation of $\mathrm{CO}_{3}$ occurs due to the reaction between $\mathrm{OH}$ - radical and bicarbonate molecules.

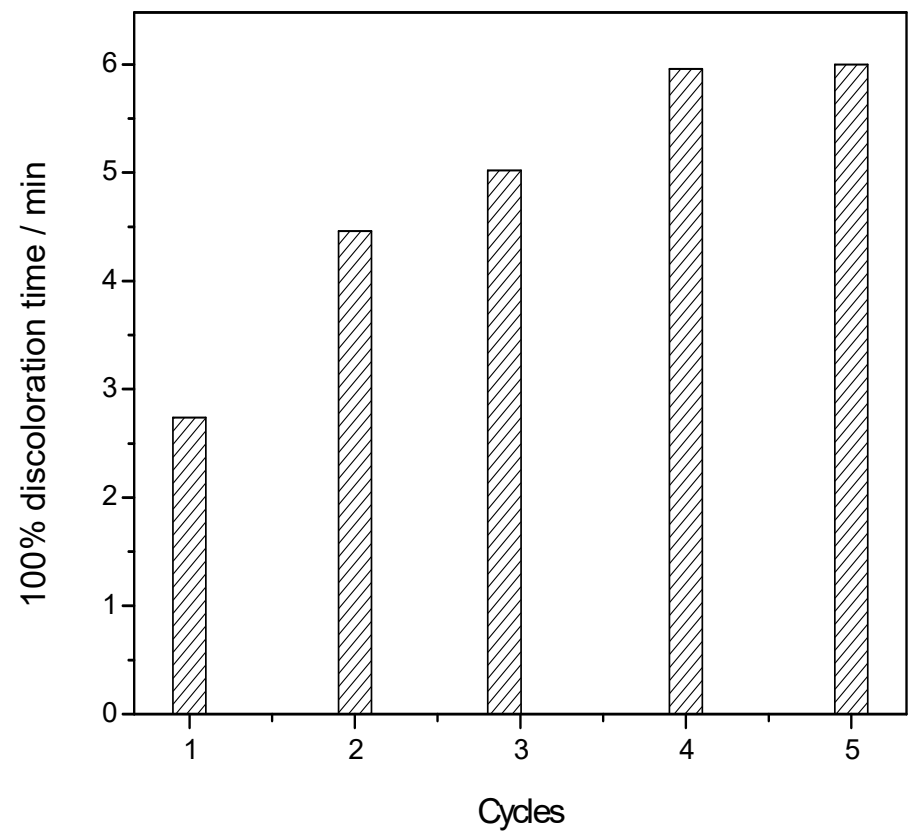

Figure 11. Successive cycles for discoloration of $\mathrm{MB}$ solution using: $[\mathrm{MB}]=6 \mathrm{ppm}+\left[\mathrm{H}_{2} \mathrm{O}_{2}\right]=0.03 \mathrm{M}+$ LIB spent cathode tape $\left(\right.$ area $\left.=16 \mathrm{~cm}^{-2}\right)+\left[\mathrm{NaHCO}_{3}\right]=0.01 \mathrm{M}$. 


\section{Conclusions}

In this work, the application of recycled Li-ion battery spent cathodes (LIB-SC) combined with the $\mathrm{NaHCO}_{3} / \mathrm{H}_{2} \mathrm{O}_{2}$ system is presented for the first time in the literature as an alternative for the degradation of potentially toxic organic molecules. The model pollutant choice was methylene blue molecules. The studied cathode has the composition $\mathrm{LiCoO}_{2}$. The porosity was calculated, and the value found was $42 \%$, with an average grain size of $32 \mu \mathrm{m}^{2}$. Regarding the decolorization of methylene blue solution, the addition of $\mathrm{NaHCO}_{3}$ reduces the time for complete decolorization from 150 to $6 \mathrm{~min}$. This reduction in time occurs due to the $\mathrm{CO}_{3}$ radical being much more stable than $\mathrm{OH}$. In this way, the application of the system proposed in this article is aimed at solving two major global problems: the disposal of cell phone batteries and the pollution of liquid effluents.

Author Contributions: R.G.T. performed the experiments; H.A.T. and E.M.G. analyzed the data and prepared the manuscript.

Funding: This work was supported by CNPq, Federal University of São João Del Rei UFSJ/Sete Lagoas/DECEB, UFSJ/DCNAT, Programa de Pós-Graduação Multicêntrico em Química (PPGMQ) and Rede Mineira de Química.

Conflicts of Interest: The authors declare no conflict of interest.

\section{References}

1. Brousselya, M.; Biensan, P.; Simon, B. Lithium insertion into host materials: The key to success for Li ion batteries. Electrochim. Acta 1999, 45, 3-22. [CrossRef]

2. Garcia, E.M.; Taroco, H.A.; Matencio, T.; Domingues, R.Z.; Santos, J.A.F.; Freitas, M.B.J.G. Electrochemical recycling of cobalt from spent cathodes of lithium-ion batteries: Its application as coating on SOFC interconnects. J. Appl. Electrochem. 2011, 41, 1373-1379. [CrossRef]

3. Georgi, M.T.; Friedrich, B.; Weyhe, R.; Heegn, H.; Rutz, M. Development of a recycling process for Li-ion batteries. J. Power Sources 2012, 207, 173-182. [CrossRef]

4. Swain, B. Recovery and recycling of lithium: A review. Sep. Purif. Technol. 2017, 172, 388-403. [CrossRef]

5. Alessandro, P.; Raana, K.S.; Sajad, Y.; Michael, P.; William, E.M. High performance bi-metallic manganese cobalt oxide/carbon nanotube li-ion battery anodes. Electrochim. Acta 2016, 213, 620-625.

6. Repp, S.; Harputlu, E.; Gurgen, S.; Castellano, M.; Kremer, N.; Pompe, N.; Worner, J.; Hoffmann, A.; Thomann, R.; Emen, F.M.; et al. Synergetic effects of $\mathrm{Fe}^{3+}$ doped spinel $\mathrm{Li}_{4} \mathrm{Ti}_{5} \mathrm{O}_{12}$ nanoparticles on reduced graphene oxide for high surface electrode hybrid supercapacitors. Nanoscale 2018, 10, 1877-1884. [CrossRef] [PubMed]

7. Genc, R.; Alas, M.O.; Harputlu, E.; Repp, S.; Kremer, N.; Castellano, M.; Colak, S.G.; Ocakoglu, K.; Emre, E. High-Capacitance Hybrid Supercapacitor Based on Multi-Colored Fluorescent Carbon-Dots. Sci. Rep. 2017. [CrossRef] [PubMed]

8. Xiao, P.; Quan, S.H.; Xie, C.J. A new supercapacitor and li-ion battery hybrid system for electric vehicle in ADVISOR. J. Phys.Conf. Ser. 2017. [CrossRef]

9. Jelena, S.; Danica, B.B.; Divna, M.; Elena, T.; Jelena, P.; Milica, V. The synthesis of Li(Co-Mn-Ni) $\mathrm{O}_{2}$ cathode material from spent-Li ion batteries and the proof of its functionality in aqueous lithium and sodium electrolytic solutions. J. Power Sources 2017, 342, 690-703.

10. Sami, V.M.F.F.; Antero, L.T.S. Solvent extraction fractionation of Li-ion battery leachate containing Li, Ni, and Co. Sep. Purif. Technol. 2017, 179, 274-282.

11. Eric, M.G.; Hosane, A.T.; Ana, P.C.M.; Amauri, G.S.; Rafael, R.A.S.; Júlio, O.F.M.; Cristiane, G.T.; Quele, C.P.T. Application of spent Li-ion batteries cathode in methylene blue dye discoloration. J. Chem. 2017, 2017. [CrossRef]

12. Kyle, S.H.; Timothy, W.M.; Ireneusz, J.; Kotchaphan, K.; Christopher, M.S.; David, M.B. Carbonate radical formation in radiolysis of sodium carbonate and bicarbonate solutions up to $250{ }^{\circ} \mathrm{C}$ and the mechanism of its second order decay. J. Phys. Chem. A 2010, 114, 2142-2150.

13. Liu, W.; Qian, J.; Wang, K.; Xu, H.; Jiang, D.; Liu, Q.; Yang, X.W.; Li, H.; Huaming, L. Magnetically Separable $\mathrm{Fe}_{3} \mathrm{O}_{4}$ Nanoparticles-Decorated Reduced Graphene Oxide Nanocomposite for Catalytic Wet Hydrogen Peroxide Oxidation. J. Inorg. Organomet. Polym. 2013, 23, 907-916. [CrossRef] 
14. Keisuke, I.; Mohamed, G.E.-D. Aqueous pesticide degradation by hydrogen peroxide/ultraviolet irradiation and Fenton-type advanced oxidation processes: A review. J. Environ. Eng. Sci. 2006, 5, 81-135.

15. Riccardo, R.; Fabio, L.M.; Colin, W.; Robert, A.H.; Yi, C. Electrochemical characterization of $\mathrm{LiCoO}_{2}$ as rechargeable electrode in aqueous $\mathrm{LiNO}_{3}$ electrolyte. Solid State Ion. 2011, 192, 289-292.

(C) 2018 by the authors. Licensee MDPI, Basel, Switzerland. This article is an open access article distributed under the terms and conditions of the Creative Commons Attribution (CC BY) license (http://creativecommons.org/licenses/by/4.0/). 